\title{
Effect of Cadmium and Lead on Quantitative and Essential Oil Traits of Peppermint (Mentha piperita L.)
}

\author{
Shahram AMIRMORADI ${ }^{1 *}$, Parviz Rezvani MOGHADDAM ${ }^{1}$, Alireza \\ KOOCHEKI ${ }^{1}$, Shahnaz DANESH ${ }^{2}$, Amir FOTOVAT ${ }^{3}$ \\ ${ }^{1}$ Ferdowsi University of Mashhad, Faculty of Agriculture, Department of Agronomy, P.O. Box 91775-1163, Mashhad, \\ Iran;shahramamirmoradi@yahoo.com (*correspondingauthor),rezvani@um.ac.ir,akooch@ferdowsi.um.ac.ir \\ ${ }^{2}$ Ferdowsi University of Mashhad, Civil Engineering Department, P.O.Box 91775-1363, Mashhad, Iran; sdanesh@ferdowsi.um.ac.ir \\ ${ }^{3}$ Ferdowsi University of Mashhad, Faculty of Agriculture, Department of Soil Science, P.O. Box 91775-1163, Mashhad, Iran; afotovat@yahoo.com
}

\begin{abstract}
Cadmium $(\mathrm{Cd})$ and lead $(\mathrm{Pb})$ are particularly noteworthy metals that can pollute the air, soil and water contributing to serious environmental problems. Tests were done on concentrations of $\mathrm{Pb}$ and $\mathrm{Cd}$; treatments tested in the experiment were as follows; Cd concentrations $(10,20,40,60,80,100 \mathrm{ppm})$ and concentrations of $\mathrm{Pb}(100,300,600,900,1200,1500 \mathrm{ppm})$ and control. Tests were done on Mentha piperita L. in a greenhouse, arranged as a randomized complete block design with three replications. Rhizomes with uniform weight were planted in pots $30 \times 50 \times 35 \mathrm{~cm}$. Plants were irrigated with $\mathrm{Cd}$ and $\mathrm{Pb}$ chloride after germination of all rhizomes. Results demonstrated that with increasing concentrations of $\mathrm{Cd}$ and $\mathrm{Pb}$ there was a decrease in fresh and dry weights, main stem height, leaf area per plant, leaf number, number of nodes per main stem and essential oil of peppermint compared to the control. Fresh weights were decreased at $100 \mathrm{ppm}$ of $\mathrm{Cd}$ and $1500 \mathrm{ppm}$ of $\mathrm{Pb}, 18.16 \%$ and $24.55 \%$, respectively compared to the control at the first harvest. At the second harvest, these decreases were $15.24 \%$ and $32.72 \%$, respectively. At the highest concentrations of $\mathrm{Cd}$ and $\mathrm{Pb}$, dry weight of peppermint was dropped $22.92 \%$ and $39.01 \%$ at the first harvest. For the second harvest, decreased dry weights were $25.88 \%$ and $26.77 \%$ respectively. It seems that peppermint can tolerate waste water or soil polluted with medium range of $\mathrm{Cd}$ and $\mathrm{Pb}$ concentrations and the essential oil percentage was not affected by these concentrations.
\end{abstract}

Keywords: heavy metals, leaf area, medicinal plant

\section{Introduction}

In the last decade medicinal plants have become more widely used in medicine (Blumenthal, 1998) and industry (Lorenzi and Matos, 2002). Medicinal plants are currently important plants in ecological agriculture. Cultivation of these plants in polluted soil or soils irrigated with wastewater may contribute to the contamination of end products. Furthermore these polluted products are not safe for human consumption and may create serious health problems (Rai et al., 2004). Research has shown that some medicinal plants can be cultivated in soil contaminated with heavy metals without evidence of these hazardous elements in end products (Zhejazkov et al., 2008). Peppermint (Mentha piperita L.) is an aromatic plant from the family of Lamiaceae, which is a hybrid of Mentha aquatica L. and Menth a spicata L. This plant has traditionally been used in medicine (Blumenthal, 1998). Peppermint oil is rich in menthol, which is a great component in the manufacturing of perfume and essence (Lorenzi and Matos, 2002). Peppermint cultivate in some Porivnce like Fars, Markazi, South Khorasan, North Khorasan, Kermanshah province. Peppermint is cultivated in some parts of Iran as a medicinal plant for industrial purpose and fresh use. Mostly Peppermint is cultivated by small holder farmers differed from year to year (100 to $1100 \mathrm{ha}$ ) and the cultivation area statistics is not clear. Industrialization has been the cause of much environmental pollution and one of the most significant pollutants is that of heavy metals. Heavy metals can cause air, water and soil pollution and may create serious problems in the biosphere (Emese $e t$ al., 2009; Street et al., 2007). Heavy metals exist worldwide as their use is widespread in industry (Chen Wang and Wang, 2005; Singh et al., 2004). Irrigation of soil with waste-water polluted with heavy metals not only causes soil pollution, but may also affect food quality and security because of gradual accumulation of heavy metals (Muchuweti et al., 2006). Cd and $\mathrm{Pb}$ are more noteworthy than other heavy metals because they are more persistent in the environment (Pendey et al., 2007). Heavy metals may accumulate in the food chain becoming hazardous for humans and livestock that are more sensitive than plants in terms of absorption of these elements (Liu et al., 2006). Toxic effects of heavy metals may cause damage to 
102

human DNA, particularly in children (Baudouin, 2002). For example toxicity from lead causes damage to the nervous system and consequently causes loss of intelligence and short-term memory, decreased learning ability and carcinogenic diseases (Soghian, 2009). Plants suitable for phytoremediation may be identified through investigation of germination parameters, plant growth and production under heavy metals contaminated media. It was reported that increasing amounts of certain heavy metals causes a decrease of germination and plant growth parameters in many plants (Jun et al., 2009; Marques et al., 2007; Sengar et al., 2008). Loss of plant biomass by increasing levels of Cd toxicity occurred because processes of chlorophyll synthesis and photosynthesis were inhibited (Padmaja, 1990). Scora and Chang (1997) reported that Mentha peperita L. planted in polluted soil contaminated with $\mathrm{Cd}$ at 0.12 to $6.1 \mathrm{ppm}$ concentrations did not demonstrate altered biomass or essential oil components, but Zheljazkov and Nielsen (1996) indicated that with increasing $\mathrm{Cd}, \mathrm{Cu}$, $\mathrm{Pb}, \mathrm{Mn}$ and $\mathrm{Zn}$ concentrations, fresh yield and essential oil yield decreased. Scavroni demonstrated that peppermint can be cultivated as a good phytoremediator in polluted soil as it was capable of developing without accumulation of these metals in its tissue (Scavroni et al., 2005). Zheljazkov et al. (2006) reported that with increasing concentrations of $\mathrm{Cd}, \mathrm{Pb}$ and $\mathrm{Cu}$ from 10 to $100 \mathrm{ppm}$, dry matter of peppermint, basil (Ocimum basilicum L.) and dill (Anethum graveolens L.) were not affected. The main goal of this study was investigation of $\mathrm{Cd}$ and $\mathrm{Pb}$ impact on fresh and dry weight, stem height, number of nodes in main stem, leaf area, number of leaf per plant and essential oil percent of peppermint.

\section{Materials and methods}

The experiment was done in the research greenhouse of the Agricultural Faculty of Ferdowsi University of Mashhad in 2011. Experimental treatments were $\mathrm{Cd}$ concentrations $(10,20,40,60,80$ and $100 \mathrm{ppm}), \mathrm{Pb}$ concentrations $(300,600,900,1200$ and $1500 \mathrm{ppm})$ and control (Khorrami Vafa et al., 2012 a, b; Zheljazkov et al., 2006). The treatments were arranged basis on a randomized block design with three replications. Solutions were prepared with $\mathrm{Cd}$ and $\mathrm{Pb}$ cholride and distilled water was used as the control. Peppermint was cultivated with uniform weight rhizomes harvested from the research farm of Ferdowsi University of Mashhad, Iran. Every rhizome had two buds and 6 rhizomes were planted in pots of dimensions $30 \times 50 \times 35 \mathrm{~cm}$. The soil of pots was brought from the farm of Ferdowsi University of Mashhad. Irrigation of pots with $\mathrm{Cd}$ and $\mathrm{Pb}$ solutions was done on the basis of field capacity when all rhizomes were germinated. Distilled water was used for the control. After irrigation with $\mathrm{Cd}$ and $\mathrm{Pb}$ solutions, all pots were irrigated with distilled water for subsequent applications. Nitrogen, phosphorus and potassium fertilizers were applied according to results of the soil analysis. First and second harvests were carried out at the stage of 10 percent flowering. After every harvest, number of leaves per plant, main stem height, number of nodes per main stem, leaf area per plant and fresh weight of plants were measured. All plants were dried in shading for 72 hours and dry weights of plants were determined. Essential oil percentage was measured by clevenger with distilled water. In this method 30 grams of peppermint leaves were dried and soaked in $400 \mathrm{ml}$ of distilled water and then were boiled in a round-bottom flask. After $120 \mathrm{~min}$, heating was stopped and essential oil percentage was measured. (Croteau et al., 2006). Data were analyzed by MSTATC software. All means were compared with Duncan's Multiple Range Test at $5 \%$ level.

\section{Results and discussion}

\section{Fresh and dry weight}

Results of analysis of variance indicated that various concentrations of $\mathrm{Cd}$ and $\mathrm{Pb}$ had significant impact $(p \leq 0.01)$ at the first harvest (Tab. 1 and 2). Increasing doses of $\mathrm{Cd}$ caused a decrease of fresh weight. This decline was $18.16 \%$ at $100 \mathrm{ppm} \mathrm{Cd}$ and was $24.55 \%$ at 1500 $\mathrm{ppm}$ of $\mathrm{Pb}$ compared to the control. At the first harvest, dry weight declined by $25.88 \%$ at $100 \mathrm{ppm}$ of $\mathrm{Cd}$ and decreased by $39.01 \%$ at the $\mathrm{Pb}$ concentration of $1500 \mathrm{ppm}$ compared to the control (Tab. 2). Cd and $\mathrm{Pb}$ on fresh and dry weights of peppermint had significant impact at 5 $(p \leq 0.05)$ and 1 percent $(p \leq 0.01)$, respectively (Tab. 3$)$. At the second harvest the highest doses of $\mathrm{Cd}$ and $\mathrm{Pb}$ caused decreases of fresh weight by $15.24 \%$ and $32.72 \%$ respectively compared to the control and decreases of dry weight by $22.93 \%$ and $26.77 \%$ respectively compared to the control, (Tab. 4). Another research tested the effect of $\mathrm{PbNo}_{3}$ concentrations $(0,0.048,0.48,4.8$ and $48 \mathrm{mM})$ on Vicia faba L. and reported that increasing $\mathrm{Pb}$ decreased fresh weight (Ahmed Kamel, 2008). Increasing doses of Cd (0, 2. 5, 5, 10, 20, 30, $30 \mathrm{mg} / \mathrm{l}, \mathrm{cdcl}_{2}$ ) caused a decline of dry weight of the aerial part of Matthiola chenopodiifolia L. and all treatments showed significant difference compared to the control (Ghaderian and Jamali Hajiani, 2010). Increasing Cd doses $(0,3,6,9,12 \mathrm{mg} / \mathrm{kg})$ on Vigna radiata L. decreased fresh and dry weights in all varieties, but varieties responded differently (Ghani, 2010). It was indicated that the impact of $\mathrm{Cdcl}_{2}(0,2,6,10 \mathrm{ppm})$ and $\mathrm{Pbcl}_{2}(0$, $50,100,500 \mathrm{ppm}$ ) had significant effects on dry weight of Mentha piperita L., Anethum graveolens L., Ocimum basilicum L. (Zheljazkov et al., 2006). Incremental Cd doses $(0,0.01,0.02,0.05,0.1 \mathrm{ppm})$ caused a decrease of root and shoot dry weights of Gossypium hirsutum L. (Aycicek et al., 2008). Tests were done on Thlaspi caerulescens L. treated with Cd $(2.5 \mathrm{mg} / \mathrm{l})$ for 14 days. Results indicated that aerial dry weight and root dry weight decreased by $14 \%$ and 28\%, respectively (Wojcik et al., 2005). It was indicated that leaf dry weight of Arabidopsis halleril L. treated with $2.5 \mathrm{mg} / \mathrm{l}$ of Cd decreased by $26 \%$ compared to the 
control (Cosio et al., 2004). Salsola kali L. was introduced as a tolerant plant $\mathrm{Cd}$ and it was reported that a dose of 5 $\mathrm{mg} / \mathrm{l}$ of Cd caused a decrease in aerial dry weight of $31 \%$ (Rosa et al., 2004). The effect of $5 \mathrm{mg} / \mathrm{l}$ of $\mathrm{Cd}$ on corn and pea affected dry weights of aerial parts by $81 \%$ and $41 \%$, respectively (Lozano-Rodriguez et al., 1997). It seems reduction in fresh and dry weight of peppermint were due to decrease in photosynthesis and respiration (Moya et al., 1993), reducing carbohydrate metabolism (Wierzbicka, 1995) and probably chlorosis (Sanita di Toopi and Gobbrielli, 1999). Disturbance in water availability (Patra $e t$ al., 2004), inhibition of nutrient uptake (Sanita di Toppi and Gabrielli, 1999) and reduced synthesis of protein or degradation of it (Blaestrasse et al., 2003) are some of the other reasons for declining of fresh and dry weight of peppermint. Wierzbicka reported that $\mathrm{Pb}$ ions caused water deficit because they disrupted the water balance. (Wierzbicka, 1995). Increasing doses of $\mathrm{Pb}(0,10,20,30,40$ ppm) had significant negative effects on water availability. High doses of $\mathrm{Cd}$ in plants may interfere in plant growth in different methods. Enzyme activity (Van Assche and Clijster, 1990), photosynthesis inhibition (Vassilev and Yordanov, 1997), stomal closure (Barcelo and Poschenrieder, 1990) and inhibition of nutrients uptake are all possible effects on plant growth that may have occurred from Cd. Increasing doses of Cd $(0,10,20,50,100 \mu \mathrm{m} / \mathrm{l})$ caused decrease of root growth resulting in decreased nutrients and water uptake and reduced respiration (Chen $e t$ al., 2003). Protein synthesis was also affected by Cd. Protein content of Cicer arietinum L. exposed to high doses of Cd, decreased by $38 \%$ percent compared to the control (Bavi et al., 2011). Reduction in protein content may have been due to reduced synthesis or degradation of protein (Blaestrasse et al., 2003). It was reported that a reduction of aerial parts of plants as a result of $\mathrm{Cd}$ may be because of reduced chlorophyll contents and photosynthesis type I activity (Shah et al., 2008). In some concentrations of $\mathrm{Cd}(10,20,40 \mathrm{ppm})$ or $\mathrm{Pb}(100,300,600,900,1200)$ fresh and dry weight of peppermint were not significant differences(Tab. 2) in the first and second harvest.

Some researchers reported that in hyper heavy metals accumulator plants, dry weight was increased more than control with increasing of heavy metal concentrations (Tang et al., 2009). On the basis of experiment of Tang et al. (2009) with increment of $\mathrm{Cd}$ concentrations from 0 to 44 ppm dry weight of Arabis paniculata Franch increased and after 44 to $267 \mathrm{ppm}$ decreased. In their research the dry weights in medium concentrations were not significant. In our study despite of declining of dry weight with increasing of $\mathrm{Cd}$ concentrations in medium doses, the differences between treatments in these concentrations were not significant.

\section{Main stem height}

Results demonstrated that tested treatments impacted significantly on main stem height at the first harvest $(p \leq 0.05)$ (Tab. 1 and 3). Main stem height of peppermint at the highest doses of $\mathrm{Cd}$ and $\mathrm{Pb}$ decreased by $17.89 \%$ and $3.69 \%$, respectively compared to the control. At the second harvest this reduction was 3.05\% and 3.6\% from $\mathrm{Cd}$ and $\mathrm{Pb}$, respectively. Another research reported effects of $\mathrm{CuSO}_{4}$ and $\mathrm{CdSO}_{4}\left(10^{-6}\right.$ and $\left.10^{-5}\right)$ on Vicia faba L. to decrease main stem (Kasim, 2005). Increased Cd in the soil of $25 \mathrm{mg} / \mathrm{kg}$ caused plant height to decline in Solanum nigrum L. (Sun et al., 2008). It was reported that plant height of Anethum graveolens L. under concentrations of $\mathrm{Cd}(2,6,10 \mathrm{mg} / \mathrm{l})$ and $\mathrm{Pb}(50,100,500 \mathrm{mg} / \mathrm{l})$ decreased, but the height of Ocimum basilicum L. was not affected by $\mathrm{Cd}$ and $\mathrm{Pb}$ (Zheljazkov et al., 2006). A study on $\mathrm{Cd}$ doses $(0,1,5,10,100,500 \mathrm{ppm})$ on Lycopersicum sculentum Mill. indicated that a high level of Cd (100 and 500 $\mathrm{ppm}$ ) caused a significant decrease in plant height (Singh et al., 2011). An increment of Cd concentration caused a reduction of plant height in corn especially at concentrations of 100 and $200 \mathrm{ppm}$ (Mihalescu et al., 2010). In the afore-mentioned study, with an increased concentration of $\mathrm{Cd}$, yellowness appeared in the aerial part of plants, especially in leaves, consequently leaves gradually dried. In two studies in hydroponic and pot cultivation on Vetiveria $z i$ zanioides $\mathrm{L}$. using $\mathrm{PbNo}_{3}$ doses both cultivation methods caused a decrease of root and shoot growth. This reduction was significant in hydroponic culture. Vetiveria zizanioides L. was introduced as a green phytoremediator and hyper-accumulator because traits of biomass, plant height and essential oil contents were not significantly affected by $\mathrm{Pb}$ (Rotkittikhun et al., 2010). A plant can be classed as a hyper accumulator if no reduction in plant biomass and height is recorded from cultivation in heavy metals con-

Tab. 1. Analysis of variance (Mean square) of impact of $\mathrm{Cd}$ and $\mathrm{Pb}$ on fresh weight, dry matter, main stem height, leaf area per plant, number of leaf per plant, number of node in main stem, leaf essential oil in the first harvest of Mentha piperita L.

\begin{tabular}{ccccccccc}
\hline & $\begin{array}{c}\text { Degree of } \\
\text { freedom }\end{array}$ & $\begin{array}{c}\text { Fresh } \\
\text { weight }\end{array}$ & $\begin{array}{c}\text { Dry } \\
\text { weight }\end{array}$ & $\begin{array}{c}\text { Main } \\
\text { stem }\end{array}$ & Leaf area & $\begin{array}{c}\text { Number of } \\
\text { leaf per plant }\end{array}$ & $\begin{array}{c}\text { Number of node } \\
\text { per main stem }\end{array}$ & Leaf essential oil \\
\hline Replication & 2 & 170.459 & 77.98 & 52.88 & 25025.076 & 2046.015 & 16.157 & 0.54 \\
Treatment & 12 & 48.84 & 29.50 & 16.958 & 2768.415 & 148.527 & 1.448 & 0.031 \\
$\quad$ Error & 24 & $12.376^{* *}$ & $6.425^{* *}$ & $5.734^{* *}$ & $822.668^{* *}$ & $29.65^{* *}$ & $0.459^{* *}$ & $0.015^{* *}$ \\
$\begin{array}{c}\text { Coefficient } \\
\text { variation(\%) }\end{array}$ & 5.60 & 8.59 & 7.35 & 8.62 & 6.25 & 5.32 & 5.11 \\
\hline
\end{tabular}

\footnotetext{
${ }^{* * *}$ : Significant at 5 and $1 \%$ probability levels, respectively
} 
104

taminated soil, these evaluations are important in terms of defining a plant as tolerant to heavy metals (Yang et al., 2004). In these plants biomass did not reduce under the lowest doses of heavy metals to critical amounts but with an increment of heavy metals concentrations from critical and later doses, plant growth was inhibited. Inhibition of plant growth was observed as yellowness, reduction of stem height and plant biomass (Wei and Zhou, 2004). In this study the impact of Cd doses $(0,20,40,60,80,100 \mathrm{ppm})$ had no significant effect on peppermint at the first harvest (Tab. 2). Increasing concentrations of $\mathrm{Pb}$ from 0 to 1200 had no significant effect on peppermint at the first harvest, but with increasing concentrations of $\mathrm{Cd}$ from 1200 to $1500 \mathrm{ppm}$, plant height significantly decreased. Although, plant height reduced at different doses of $\mathrm{Cd}$ and $\mathrm{Pb}$, differences between concentrations was not significant (Tab. 4). It seems increasing $\mathrm{Cd}$ and $\mathrm{Pb}$ concentrations gradually decreased growth of peppermint and decreased cell length which caused to decrease the plant height, as it was mentioned by other researchers. For instance it was reported that when heavy metals were transferred to the aerial parts of plants causing disturbance in cell metabolism and reducing plant height (Shanker et al., 2005). Reduction in growth may be due to loss of cell turgor and reduction in mitosis activity or inhibition of cell elongation. For example Cd in plant cells can influence cell walls specially the middle layer of a cell wall that causes an increasing in cell width instead of cell length (Hassan et al., 2006).

\section{Leaf area per plant}

Effects of $\mathrm{Cd}$ and $\mathrm{Pb}$ concentrations on leaf area of peppermint was significant at the first harvest $(p \leq 0.01)$, but was not significant at the second harvest (Tab. 1 and 3). At the first harvest, leaf area decreased by $7.37 \%$ at 100 ppm of $\mathrm{Cd}$ and $22.21 \%$ at $1500 \mathrm{ppm} \mathrm{Pb}$ compared to the control (Tab. 2). Leaf area of Phaseolus mungo L. under
Cd treatments $0,10^{-2}, 10^{-4}, 10^{-5}, 10^{-8} \mathrm{~m} / \mathrm{l}$ was reported by Siddhu and Khan (2012). Increasing Cd concentrations to above $10^{-2} \mathrm{~m} / \mathrm{l}$ caused leaf twisting and leaf abscission that reduced leaf area. High doses of Cd in soil (100 and $500 \mu \mathrm{g} / \mathrm{kg}$ ) caused a significant reduction in leaf area in tomato (Singh et al., 2011). This reduction in leaf area was due to reduced leaf area expansion and leaf senescence. Other research reported a reduction in leaf area of tomato under $\mathrm{CdNO}_{3}$ concentrations $(150,450,900 \mathrm{mg} / \mathrm{kg}$ soil) compared to the control (Zhao et al., 2011). Increasing doses of $\mathrm{Pb}(0,4,6,8 \mathrm{~g} / \mathrm{kg}$ soil $)$ and $\mathrm{Cd}(0,150,450,900$ $\mathrm{g} / \mathrm{kg}$ soil) caused a decrease of leaf area of Phaseolus vulgaris $\mathrm{L}$ by $16.87 \%, 56.27 \%, 68.62 \%$ and $79.78 \%$ for $\mathrm{Pb}$ and $22.96 \%, 63.47 \%$ and $84.91 \%$ for Cd compared to the control (Bhardwaj et al., 2009). It seems that based on literatures the reduction of leaf area of peppermint in our study was due to impact of $\mathrm{Pb}$ on hystological changes in leaves (Elzbieta and Miroslawa, 2005).

It was reported that there was a negative relation between the increment of $\mathrm{Cd}$ dose and specific leaf area (Barcelo et al., 1988 a). Reduction in turgor pressure of plant cells treated by $\mathrm{Cd}$ and reduction of cell wall elasticity caused the formation of small cells and fewer spaces between plant cells. Reduction of turgor pressure occurred from a disturbed water balance. Research reported that Cd impacted in terms of decreased water uptake, water translocation and respiration (Vassilev et al., 1997). Reduction of water uptake in plants treated with $\mathrm{Cd}$ was due to reduced root growth. Hydraulic conductivity of water from roots to xylems depends on the degree of $\mathrm{Cd}$ stress and plant characteristics of bean, soybean and Acer pseudoplatanus L. that decreased two to four times (Barcelo et al., 1988 b; Lamoreaux and Chaney, 1977; Marchiol et al., 1996).

The decline in leaf area of peppermint with increasing of $\mathrm{Cd}$ and $\mathrm{Pb}$ doses were probably due to reduction in cell

Tab. 2. Means of $\mathrm{Cd}$ and $\mathrm{Pb}$ effects on fresh weight $(\mathrm{g})$, dry matter $(\mathrm{g})$, main stem height $(\mathrm{cm})$, leaf area per plant $\left(\mathrm{cm}^{2}\right)$, number of leaf per plant, number of node in main stem, leaf essential oil(\%) in the first harvest of Mentha piperita L.

\begin{tabular}{cccccccc}
\hline Treatment & $\begin{array}{c}\text { Fresh } \\
\text { weight }(\mathrm{g})\end{array}$ & $\begin{array}{c}\text { Dry weight } \\
(\mathrm{g})\end{array}$ & $\begin{array}{c}\text { Main stem } \\
\text { height }(\mathrm{cm})\end{array}$ & $\begin{array}{c}\text { Leaf } \\
\text { area }\left(\mathrm{cm}^{2}\right)\end{array}$ & $\begin{array}{c}\text { Number of } \\
\text { leaf per plant }\end{array}$ & $\begin{array}{c}\text { Number of node } \\
\text { per main stem }\end{array}$ & $\begin{array}{c}\text { Leaf essential } \\
\text { oil }(\%)\end{array}$ \\
\hline Control & $73.07 \mathrm{a}$ & $37.78 \mathrm{a}$ & $37.86 \mathrm{a}$ & $371.1 \mathrm{a}$ & $98.46 \mathrm{a}$ & $14.16 \mathrm{a}$ & $2.59 \mathrm{a}$ \\
$\mathrm{Cd}-10 \mathrm{ppm}$ & $64.11 \mathrm{~b}$ & $30.49 \mathrm{~b}$ & $33.84 \mathrm{ab}$ & $368.1 \mathrm{a}$ & $94.49 \mathrm{ab}$ & $13.23 \mathrm{ab}$ & $2.46 \mathrm{ab}$ \\
$\mathrm{Cd}-20 \mathrm{ppm}$ & $63.12 \mathrm{~b}$ & $29.55 \mathrm{~b}$ & $32.8 \mathrm{~b}$ & $332.3 \mathrm{abcde}$ & $88.54 \mathrm{abcde}$ & $12.82 \mathrm{~b}$ & $2.45 \mathrm{abc}$ \\
$\mathrm{Cd}-40 \mathrm{ppm}$ & $62.45 \mathrm{~b}$ & $29.25 \mathrm{~b}$ & $32.46 \mathrm{~b}$ & $338.9 \mathrm{abcde}$ & $86.55 \mathrm{bcde}$ & $12.69 \mathrm{~b}$ & $2.43 \mathrm{abc}$ \\
$\mathrm{Cd}-60 \mathrm{ppm}$ & $61.12 \mathrm{bc}$ & $28.62 \mathrm{~b}$ & $31.76 \mathrm{~b}$ & $309.6 \mathrm{bcde}$ & $82.58 \mathrm{cdef}$ & $12.41 \mathrm{bc}$ & $2.4 \mathrm{bc}$ \\
$\mathrm{Cd}-80 \mathrm{ppm}$ & $60.46 \mathrm{bc}$ & $28.31 \mathrm{~b}$ & $31.42 \mathrm{~b}$ & $292.3 \mathrm{cde}$ & $80.59 \mathrm{def}$ & $12.28 \mathrm{bc}$ & $2.38 \mathrm{bc}$ \\
$\mathrm{Cd}-100 \mathrm{ppm}$ & $59.80 \mathrm{bc}$ & $28.00 \mathrm{~b}$ & $31.08 \mathrm{bc}$ & $286.5 \mathrm{e}$ & $78.61 \mathrm{ef}$ & $12.15 \mathrm{bc}$ & $2.38 \mathrm{bc}$ \\
\hline $\mathrm{Pb}-100 \mathrm{ppm}$ & $65.11 \mathrm{~b}$ & $30.49 \mathrm{~b}$ & $33.84 \mathrm{ab}$ & $365.9 \mathrm{a}$ & $94.49 \mathrm{ab}$ & $13.23 \mathrm{ab}$ & $2.35 \mathrm{ab}$ \\
$\mathrm{Pb}-300 \mathrm{ppm}$ & $64.46 \mathrm{~b}$ & $30.17 \mathrm{~b}$ & $33.49 \mathrm{ab}$ & $355.0 \mathrm{ab}$ & $92.51 \mathrm{abc}$ & $13.09 \mathrm{ab}$ & $2.3 \mathrm{abc}$ \\
\hline $\mathrm{Pb}-600 \mathrm{ppm}$ & $63.78 \mathrm{~b}$ & $29.87 \mathrm{~b}$ & $33.15 \mathrm{~b}$ & $346.5 \mathrm{abc}$ & $90.52 \mathrm{abcd}$ & $12.95 \mathrm{ab}$ & $2.3 \mathrm{abc}$ \\
$\mathrm{Pb}-900 \mathrm{ppm}$ & $63.12 \mathrm{~b}$ & $29.55 \mathrm{~b}$ & $32.8 \mathrm{~b}$ & $343.9 \mathrm{abcd}$ & $88.53 \mathrm{abcde}$ & $12.82 \mathrm{~b}$ & $2.28 \mathrm{abc}$ \\
\hline $\mathrm{Pb}-1200 \mathrm{ppm}$ & $61.12 \mathrm{bc}$ & $28.62 \mathrm{~b}$ & $31.76 \mathrm{~b}$ & $322.2 \mathrm{abcde}$ & $82.58 \mathrm{cdef}$ & $12.41 \mathrm{bc}$ & $2.25 \mathrm{bc}$ \\
$\mathrm{Pb}-1500 \mathrm{ppm}$ & $55.13 \mathrm{c}$ & $23.04 \mathrm{c}$ & $27.05 \mathrm{c}$ & $291.0 \mathrm{de}$ & $74.64 \mathrm{f}$ & $11.21 \mathrm{c}$ & $2.2 \mathrm{c}$ \\
\hline
\end{tabular}

Means in treatments followed by similar letter are not significantly different at $5 \%$ probability level, using Duncan's Multiple Range Test (DMRT) 
Tab. 3. Analysis of variance (Mean square) of impact of $\mathrm{Cd}$ and $\mathrm{Pb}$ on fresh weight, dry matter, main stem height, leaf area per plant, number of leaf per plant, number of node in main stem, leaf essential oil in the first harvest of Mentha piperita L.

\begin{tabular}{ccccccccc}
\hline & $\begin{array}{c}\text { Degree of } \\
\text { freedom }\end{array}$ & $\begin{array}{c}\text { Fresh } \\
\text { weight }\end{array}$ & $\begin{array}{c}\text { Dry } \\
\text { weight }\end{array}$ & $\begin{array}{c}\text { Main stem } \\
\text { height }\end{array}$ & Leaf area & $\begin{array}{c}\text { Number of } \\
\text { leaf per plant }\end{array}$ & $\begin{array}{c}\text { Number of node } \\
\text { per main stem }\end{array}$ & $\begin{array}{c}\text { Leaf essential } \\
\text { oil }\end{array}$ \\
\hline Replication & 2 & 121.70 & 17.55 & 83.28 & 5260.67 & 328.615 & 5.94 & 0.063 \\
Treatment & 12 & 28.49 & 8.72 & 27.24 & 640.53 & 41.07 & 1.26 & 0.01 \\
Error & 24 & $12.68^{*}$ & $2.69^{* *}$ & $10.75^{*}$ & $366.00^{\text {ns }}$ & $18.21^{*}$ & $0.42^{* *}$ & $0.004^{* *}$ \\
$\begin{array}{c}\text { Coefficient } \\
\text { variation(\%) }\end{array}$ & 9.58 & 9.58 & 8.79 & 10.75 & 10.05 & 8.81 & 6.28 & 5.04 \\
\hline
\end{tabular}

***: Significant at 5 and $1 \%$ probability levels, respectively

division, cell differentiation of cambium cells. Barcelo et al. (1988 b) reported that water movement in bean was due to a reduction of vascular ray and vascular bundles caused by $\mathrm{Cd}$ induction and cell division, cell elongation and differentiation of cambium cells (Barcelo et al., 1988 b). These researches assumed that these events were due to hormonal disturbance but data was not shown in support of this assumption. Another reason for the reduction of water movement was due to the disturbance of vascular structures because of deposition of non-soluble phenolic compounds (Fuhrer, 1982) and lignin and sequestration of calcium oxalate (Van Balen et al., 1980). These events caused a reduction of water potential and consequently relative water content in leaves. Therefore, components of leaf water potential, treated by $\mathrm{Cd}$ decreased. Reduction of turgor pressure may be due to inappropriate osmotic adjustment because even this is a proper mechanism for stability of water balance in plants (Yancey et al., 1982). It was reported that cell turgor in plant leaves treated by $\mathrm{Cd}$ had a lower threshold of relative water content compared to the control. The reason for this loss of water was reduced cell wall elasticity due to the decomposition of phenolic and cellulose compounds in cell walls and the replacement of $\mathrm{Cd}$ with calcium in the middle lamella inside cell walls (Barcelo et al., 1986). Vazquez (1989) reported that reduction of cell elasticity was due to decreased synthesis of cell wall components because of reduced function of Golgi apparatus.

\section{Number of leaf per plant and number of node per main stem}

At the first harvest, effects of $\mathrm{Cd}$ and $\mathrm{Pb}$ concentrations on number of leaves per plant and number of nodes per main stem $(p \leq 0.01)$ were significant (Tab. 1$)$. At the second harvest the impact of treatments on number of leaves per plant $(p \leq 0.05)$ and on number of nodes per main stem $(p \leq 0.05)$ was significant (Tab. 3). Number of leaves per plant decreased at $100 \mathrm{ppm}$ of $\mathrm{Cd}$ and $1500 \mathrm{ppm}$ of $\mathrm{Pb}$ $21.16 \%$ and $24.19 \%$ respectively compared to the control at the first harvest. The number of nodes per main stem declined at the highest doses of $\mathrm{Cd}$ and $\mathrm{Pb} 14.19 \%$ and $20.83 \%$, respectively compared to the control at the first harvest (Tab. 3). Other research reported that increasing $\mathrm{Pb}$ doses $(0,5,10,15,20,25 \mu \mathrm{m} / \mathrm{M})$ caused a decrease of leaf number in Thespesia populnea L. (Kabir et al., 2010). It was reported that incremental concentrations of $\mathrm{Cd}$ after $0.1 \mu \mathrm{m} / \mathrm{M}$ caused a reduction of leaf number in tomato. For example 30 days after planting in a concentration of

Tab. 4. Means of cadmium and lead effects on fresh weight $(\mathrm{g})$, dry matter $(\mathrm{g})$, main stem height $(\mathrm{cm})$, leaf area per plant $\left(\mathrm{cm}^{2}\right)$, number of leaf per plant, number of node in main stem, leaf essential oil(\%) in the first harvest of Mentha piperita L.

\begin{tabular}{cccccccc}
\hline Treatment & $\begin{array}{c}\text { Fresh } \\
\text { weight }(\mathrm{g})\end{array}$ & $\begin{array}{c}\text { Dry weight } \\
(\mathrm{g})\end{array}$ & $\begin{array}{c}\text { Main stem } \\
\text { height }(\mathrm{cm})\end{array}$ & $\begin{array}{c}\text { Leaf area } \\
\left(\mathrm{cm}^{2}\right)\end{array}$ & $\begin{array}{c}\text { Number of } \\
\text { leaf per plant }\end{array}$ & $\begin{array}{c}\text { Number of node } \\
\text { per main stem }\end{array}$ & $\begin{array}{c}\text { Leaf essential } \\
\text { oil }(\%)\end{array}$ \\
\hline Control & $43.02 \mathrm{a}$ & $23.64 \mathrm{a}$ & $39.78 \mathrm{a}$ & $231.3 \mathrm{a}$ & $57.33 \mathrm{a}$ & $12.18 \mathrm{a}$ & $1.27 \mathrm{ab}$ \\
$\mathrm{Cd}-10 \mathrm{ppm}$ & $39.1 \mathrm{a}$ & $19.93 \mathrm{~b}$ & $31.76 \mathrm{~b}$ & $194.1 \mathrm{~b}$ & $49.75 \mathrm{abc}$ & $10.53 \mathrm{~b}$ & $1.29 \mathrm{a}$ \\
$\mathrm{Cd}-20 \mathrm{ppm}$ & $37.83 \mathrm{a}$ & $19.11 \mathrm{~b}$ & $30.30 \mathrm{~b}$ & $190.4 \mathrm{~b}$ & $48.83 \mathrm{bc}$ & $10.29 \mathrm{~b}$ & $1.20 \mathrm{ab}$ \\
$\mathrm{Cd}-40 \mathrm{ppm}$ & $37.55 \mathrm{a}$ & $18.59 \mathrm{~b}$ & $29.74 \mathrm{~b}$ & $199.2 \mathrm{ab}$ & $51.01 \mathrm{ab}$ & $10.15 \mathrm{~b}$ & $1.21 \mathrm{ab}$ \\
$\mathrm{Cd}-60 \mathrm{ppm}$ & $36.37 \mathrm{a}$ & $18.18 \mathrm{~b}$ & $28.88 \mathrm{~b}$ & $181.7 \mathrm{~b}$ & $46.63 \mathrm{bc}$ & $9.96 \mathrm{~b}$ & $1.18 \mathrm{ab}$ \\
\hline $\mathrm{Cd}-80 \mathrm{ppm}$ & $36.3 \mathrm{a}$ & $18.01 \mathrm{~b}$ & $28.60 \mathrm{~b}$ & $177.4 \mathrm{~b}$ & $45.6 \mathrm{bc}$ & $9.88 \mathrm{~b}$ & $1.16 \mathrm{~b}$ \\
$\mathrm{Cd}-100 \mathrm{ppm}$ & $36.46 \mathrm{a}$ & $18.22 \mathrm{~b}$ & $28.5 \mathrm{~b}$ & $183.0 \mathrm{~b}$ & $46.96 \mathrm{bc}$ & $9.81 \mathrm{~b}$ & $1.18 \mathrm{ab}$ \\
\hline $\mathrm{Pb}-100 \mathrm{ppm}$ & $38.65 \mathrm{a}$ & $19.04 \mathrm{~b}$ & $31.00 \mathrm{~b}$ & $199.6 \mathrm{ab}$ & $51.23 \mathrm{ab}$ & $10.66 \mathrm{~b}$ & $1.25 \mathrm{ab}$ \\
$\mathrm{Pb}-300 \mathrm{ppm}$ & $38.62 \mathrm{a}$ & $18.72 \mathrm{~b}$ & $30.67 \mathrm{~b}$ & $191.8 \mathrm{~b}$ & $49.06 \mathrm{bc}$ & $10.53 \mathrm{~b}$ & $1.22 \mathrm{ab}$ \\
$\mathrm{Pb}-600 \mathrm{ppm}$ & $37.68 \mathrm{a}$ & $18.00 \mathrm{~b}$ & $30.78 \mathrm{~b}$ & $186.7 \mathrm{~b}$ & $48.10 \mathrm{bc}$ & $10.38 \mathrm{~b}$ & $1.24 \mathrm{ab}$ \\
$\mathrm{Pb}-900 \mathrm{ppm}$ & $36.12 \mathrm{a}$ & $17.24 \mathrm{~b}$ & $30.10 \mathrm{~b}$ & $186.6 \mathrm{~b}$ & $47.82 \mathrm{bc}$ & $10.41 \mathrm{~b}$ & $1.23 \mathrm{ab}$ \\
$\mathrm{Pb}-1200 \mathrm{ppm}$ & $36.72 \mathrm{a}$ & $16.95 \mathrm{~b}$ & $28.96 \mathrm{~b}$ & $179.2 \mathrm{~b}$ & $45.98 \mathrm{bc}$ & $9.74 \mathrm{~b}$ & $1.22 \mathrm{ab}$ \\
$\mathrm{Pb}-1500 \mathrm{ppm}$ & $28.94 \mathrm{~b}$ & $17.31 \mathrm{~b}$ & $27.75 \mathrm{~b}$ & $174.1 \mathrm{~b}$ & $41.47 \mathrm{c}$ & $9.63 \mathrm{~b}$ & $1.06 \mathrm{c}$ \\
\hline
\end{tabular}

Means in treatments followed by similar letter are not significantly different at $5 \%$ probability level, using Duncan's Multiple Range Test (DMRT) 
106

$10 \mu \mathrm{m} / \mathrm{M}$ leaf number reduced by $31.5 \%$ compared to the control (Jing et al., 2005). It was reported that with an increment of Cd doses $\left(0,10^{-10}, 10^{-8}, 10^{-5}, 10^{-2} \mathrm{~m}\right)$ leaf number and leaf area of bean decreased (Siddhu and Khan, 2012). It seems absorption and translocations of $\mathrm{Cd}$ and $\mathrm{Pb}$ in aerial parts of a plant can disturb the cell metabolism in the stem and that will decrease plant height and number of nodes per plant (Shanker et al., 2005). Reductions in plant growth may be due to loss of cell turgor and mitosis activity or cell expansion and elongation. These $\mathrm{Cd}$ can inhibit the elongation of plant cells by means of replacement $\mathrm{Cd}$ instead of $\mathrm{Ca}$ in cell walls that increases cell width instead of cell length (Hassan et al., 2006). These events may affect the nodes of a stem. It was reported that an incremental dose of $\mathrm{Cd}$ reduced plant height, number of leaves and dry weight of tomato (El-Gamal and Hammad, 2003). The reason for this may be the reduction of water uptake, reduction of synthesis of photosynthetic pigments, carbohydrates and soluble sugars. Increment of Cd doses reduced growth and leaf number in soybean, and the maximum reduction of leaf number was $44.4 \%$ at 200 ppm of Cd (Abdo et al., 2012). Fouda and Arafa (2002) also reported that high doses of $\mathrm{Cd}$ reduced plant height, leaf number and leaf area of soybean. An increment of $\mathrm{Pb}$ caused water stress and consequently reduced the leaf area, photosynthesis, dry weight and plant height and number of nodes in soybean (Azmat et al., 2009).

\section{Essential oil percentage}

Impact of $\mathrm{Cd}$ and $\mathrm{Pb}$ concentrations on leaf essential oil of peppermint was significant $(p \leq 0.01)$ at the first and second harvests (Tab. 1 and 3). At the first harvest, essential oil percentage was decreased by $8.10 \%$ and $15.05 \%$ at the $100 \mathrm{ppm}$ of Cd and $1500 \mathrm{ppm}$, respectively compared to the control. This reduction was $7.08 \%$ and $16.53 \%$ at the second harvest compared to the control (Tab. 2 and 4). It was reported that the impact of Cd concentrations $(2,6$, $10 \mathrm{mg} / \mathrm{l})$ and $\mathrm{Pb}$ concentrations $(50,100,500 \mathrm{mg} / \mathrm{l})$ on essential oil of peppermint was not significant but decreased essential oil percentages of dill and basil (Zheljazkov et al., 2006). The impact of chromium on hypericin content in Hypericum perforatum L. was not significant (Tirillini et al., 2006). Using the compost consists of $\mathrm{Cu}(311 \mathrm{mg} / \mathrm{kg})$, $\mathrm{Pb}(223 \mathrm{mg} / \mathrm{kg}), \mathrm{Mo}(17 \mathrm{mg} / \mathrm{kg})$ and $\mathrm{Zn}(767 \mathrm{mg} / \mathrm{kg})$ decreased essential oil content of basil, but the essential oil was free of heavy metals (Zheljazkov and Philip, 2003). It was reported that leaf essential oil content of Lavandula vera D. C. was not affected by heavy metals (Zheljazkov and Nielsen, 1993). Essential oil of peppermint extracted from leaves and stems may depend on dry matter, which is produced by leaves and stems. More essential oil yield depends on more dry matter of the aerial parts of plants (Czepak, 1998). Although it was indicated that there was no difference between essential oil yields of peppermint cultivated in polluted soil to heavy metals and the control (Scora and Chang, 1997). Essential oil yield of pepper- mint decreased in plants cultivated in compost contaminated with heavy metals (Topalov and Zheljazkov, 1991). It was demonstrated that terpenoids produced in epidermal glands in peppermint leaves consumed the carbon provided by photosynthesis (Croteau and Johnson, 1984). Synthesis of peppermint essential oil in epidermal glands depends on providing the photosynthetic carbon and disturbance in carbon nutrition that can cause a reduction of essential oils (Srivastava et al., 1994). As it was mentioned in literature, it seems synthesis of essential oil of peppermint affected by high doses of $\mathrm{Cd}$ and $\mathrm{Pb}$ concentrations due to disturbing on carbon translocations and toxic effects of these heavy metals and consequently essential oil percent was reduced.

\section{Conclusion}

Increasing concentrations of $\mathrm{Cd}$ and $\mathrm{Pb}$ decreased fresh and dry weights of peppermint at the first and second harvest compared to the control. Main stem height reduced at the first harvest more than the second harvest. Impact of treatments on leaf area per plant was significant at the first harvest, but at the second harvest it was not significant. Effect of $\mathrm{Cd}$ and $\mathrm{Pb}$ concentrations on essential oil percentage was significant and increasing doses of $\mathrm{Cd}$ and $\mathrm{Pb}$ reduced essential oil percentages. Although fresh and dry weights and essential oil percentages decreased with increasing concentrations of $\mathrm{Cd}$ and $\mathrm{Pb}$, means comparison indicated that differences between treatments were not significant. It seems that peppermint can be cultivated in conditions of polluted soil or wastewater polluted with $\mathrm{Cd}$ and $\mathrm{Pb}$.

\section{Acknowledgment}

The authors acknowledge the financial support of the project by Ferdowsi University of Mashhad. We thank Mr. Nejati for his providing valuable help during experiment.

\section{References}

Abdo FA, Nassar DMA, Gomaa EF, and Nassar RMA (2012). Minimizing the harmful effects of cadmium on vegetative growth, leaf anatomy, yield and physiological characteristics of soybean plant [Glycine max (L.) Merrill] by foliar spray with active yeast extract or with garlic cloves extract. Research J of Agric and Biol Sci 8(1):24-35.

Ahmad Kamel H (2008). Lead accumulation and its effect on photosynthesis and free amino acids in Vicia faba grown hydroponically. Aust J of Basic and App Sci 2(3):438-446.

Aycicek M, Ince M, Yaman M (2008). Effects of cadmium on the germination, early seedling growth and metal content of cotton (Gossypium hirsutum L.). Int J of Sci and Tech $3(1): 1-11$.

Azmat R, Haider S, Hajra N, Farha A (2009). A viable alternative mechanism in adapting the plants to heavy metal envi- 
ronment. Pak J of Bot 41(6):2729-2738.

Barcelo J, Pochenrieder Ch, Andreu I (1986). Cadmium-induced decrease of water stress resistance in bush bean plants (Phaseolus vulgaris L. cv. 'Contender'). I. Effects of cd on water potential, relative water content and cell wall elasticity. J of Plant Physiol 125:17-25.

Barcelo J, Poschenrieder C (1990). Plant water relations as affected by heavy metal stress: a review. J of Plant Nut 13:137.

Barcelo J, Vazquez M, Poschenrieder Ch (1988 a). Cadmiumindused structural and ultrastuctural changes in the vascural system of bush bean stems. Botanica Acta 101:254-261.

Baudouin C, Charveron M, Tarrouse R, Gall Y (2002). Environmental pollutants and skin cancer. Cell Biol Toxic 18:341-348.

Bavi Kh, Kholdebarin B, Moradshahi A (2011). Effect of cadmium on growth, protein content and peroxidase activity in pea plants. Pak J Bot 43(3):1467-1470.

Bhardwaj P, Ashish K, Prasadi P (2009). Effect of enhanced lead and cadmium in soil on physiological and biochemical attributes of Phaseolus vulgaris L. Nature and Sci 7(8).

Blaestrasse KB, Benavides MP, Gallego SM, Tomaro ML (2003). Effect of cadmium stress on nitrogen metabolism in nodules and roots of soybean plants. Funct Plant Biol 30: 57-64.

Blumenthal M (1998). The complete german commission monographs: therapeutic guide to herbal medicines. Austin: American Botanical Council.

Chen YX, He YF, Luo YM, Yu YL, Lin Q, Wong MH (2003). Physiological mechanism of plant roots exposed to cadmium. Chemos 50:789-793.

Chen Y, Wang C, Wang Z (2005). Residues and source identification of persistent organic pollutants in farmland soils irrigated by effluents from biological treatment plants. Environ Int 31:778-783.

Cosio C, Martinoia E, Keller C (2004). Hyperaccumulation of cadmium and zinc in Thlaspi caerulescens and Arabidopsis halleri at the leaf cellular level. Plant Physiol 134:716-725.

Croteau R, Johnson MA (1984). Biosynthesis of terpenoids in glandular trichomes. Chem of Plant Trichomes, 133-185 p.

Croteau R, Burbott AJ, Lommis WD (2006). Biosynthesis of mono and sesquiterpenes in peppermint. Phytochem 71:2937-2948.

Czepak MP (1998). Produção de óleo bruto e mentol cristalizável em oito freqüências de colheita da menta (Menta arvensis L.). Sci Botucatu, 53-80 p.

El-Gamal SM, Hammad SAR (2003). Counteracting the deleterious effects of lead and cadmium on tomato plants by using yeast, garlic and eucalyptus extracts. Minufiya J Agri Res 28(3):737-755.

Elzbieta WC, Chwil M (2005). Lead-induced histological and ultra structural changes in the leaves of soyben (Glycine max (L) Mee.). Soil Sci Plant Nut 51:203-212.

Emese S, Rita A, Katalin G, Gabriella MG (2009). Change of
107

bioaccumulation of toxic metals in vegetables. Community. Soil Sci. Plant Anal 40:285-293.

Fouda RA, Arafa AA (2002). Alleviation of cadmium toxicity on soybean, Glycine $\max$ (L.) Merr. by inoculation with bradyrhizobium and vesicular-arbuscular mycorrhizae or kinetin. J Agric Sci Mansoura Univ 27(11):7385-7403.

Fuhrer J (1982). Ethylene biosynthesis and cadmium toxicity in leaf tissue of beans (Phaseolus vulgaris L.). Plant Physiol 70:162-167.

Ghaderian SM, Jamali Hajiani N (2010). Tolerance, uptake and accumulation of cadmium in Matthiola chenopodiffolia Fisch and C. A. Mey (Brassicaceae). J of Plant Biol 6:87-98.

Ghani A (2010). Effect of cadmium toxicity on the growth and yield components of mungbean [Vigna radiata (L.) Wilczek]. World Appl Sci (Special Issue of Biotech and Genetic Engin) 8:26-29.

Hassan MJ, Zhu Z, Ahmad B, Mahmood Q (2006). Influence of cadmium toxicity on rice genotypes as affected by zinc, sulfur and nitrogen fertilizers. Casp J Environ Sci 4(1):1-8.

Jing D, Fei-bo WU, Guo-ping Zh (2005). Effect of cadmium on growth and photosynthesis of tomato seedlings. J of Zhejiang Univ Sci 6(10):974-980.

Jun R, Ling T, Guanghua Z (2009). Effects of chromium on seed gemination, root elongation and coleoptile growth in six pulses. Int J Environ Sci Tech 6:571-578.

Kabir M, Iqbal MZ, Shafiq M, Farooqi ZR (2010). Effects of lead on seedling growth of Thespesia populnea L. Plant Soil Environ 56 (4):194-199.

Kasim WA (2005). The correlation between physiological and structural alterations induced by copper and cadmium stress in broad beans (Vicia faba L.). Egypt J of Biol 7:20-32.

Lamoreaux R, Chaney W (1977). Growth and water movement in silver maple seedlings affected by cadmium. J Environ Qual 6(2):201-204.

Khorrami Vafa M, Shokri K, Sayyadian K, Rejali F (2012 a). The Combined Effects of Sulfur, Thiobacilli and Mycorrizal Fungi on Lead Uptake by Mentha $\times$ Piperita). American $J$ Sci Res pp. 84-91.

Khorrami Vafa M, Shokri K, Sayyadian K, Rejali F (2012 b). Contribution of microbial associations to the cadmium uptake by peppermint (Mentha piperita). Ann of Biol Res 3(5):2325-2329.

Lorenzi H, Matos FJA (2002). Plantas medicinais no Brasil: nativas e exóticas cultivadas. Nova Odessa: Instituto Plantarum, $544 \mathrm{p}$.

Lozano-Rodriguez E, Hernandez LE, Bonay P, Carpena-Ruiz RO (1997). Distribution of cadmium in shoot and root tissues of maize and pea plants: physiological disturbances. J Exp Bot 48(306):123-128.

Liu W-X, Li H-H, Li S-R, Wang Y-W (2006). Heavy metal accumulation of edible vegetables cultivated in agricultural soil in the suburb of Zhengzhou city, People's Republic of China. Bullt of Environ Cont Toxic 76:163-170. 
108

Marchiol L, Leita L, Martin M, Peterssotti A, Zerbi G (1996). Physiological responses of two soybean cultivars to cadmium. J Environ Qual 25:562-566.

Marques PGC, Rangel OSS, Castro ML (2007). Effect of arsenic, lead and znic on seed germination and plant growth in black nightshade (Solanum nigrum L.) vs. clover (Trifolium incarnatum L.). Fresenius Eviron Bullt 16:896-903.

Mihalescu LA, Mare-Rosca OE, Marian M, Bildar CF (2010). Research on the growth intensity of the Zea mays L. plantlets aerial parts under cadmium treatment. Analele Universitatii din Oradea, Fascicula Biologie, 147-151 p.

Moya JL, Ros R, Picazo I (1993). Influence of cadmium and nickel on growth, net photosynthesis and carbohydrate distribution in rice plants. Photosynt Res 36:75-80.

Muchuweti M, Birkett J W, Chinyanga E, Zvauya R, Scrimshaw M D, Lester JN (2006). Heavy metal content of vegetables irrigated with mixture of wastewater and sewage sludge in Zimbabwe: implications for human health. Agri, Ecos and Environ 112:41-48.

Padmaja K, Parsad DK, Parsad AR (1990). Inhibition of chlorophyll synthesis in Phaseolus vulgaris L. seedlings by cadmium acetate. Photosynthetica 24:399-404.

Pendey SK (2007) Gupta and A.K. Mukharjee: Impact of cadmium and lead on Catharanthus roseus- A phytoremediation study. J Environ Biol 28:655-662.

Patra M, Bhowmik N, Bandopadhyay B, Sharma A (2004). Comparison of mercury, lead and arsenic with respect to genotoxic effects on plant systems and the development of genetic tolerance. Environ Exp Bot 52:199-223.

Rai V, Vaypayee P, Singh SN, Mehrotra S (2004) Effect of chromium accumulation on photosynthetic pigments, oxidative stress defense system, nitrate reduction, proline level and eugenol content of Ocimum tenuiflorum. Plant Sci 167:1159-1164.

Rosa G, Peralta-Videa JR, Montes M, Parsons JG, Cano-Aguilera I, Gardea-Torresdey JL (2004). Cadmium uptake and translocation in tumbleweed (Salsola kali), a potential Cdhyperaccumulator desert plant species: ICP/OES and XAS studies. Chemos 55:1159-1168.

Rotkittikhun P, Kruatrachue M, Pokethitiyook P, Baker AJM (2010). Tolerance and accumulation of lead in Vetiveria $z i$ zanioides and its effect on oil production. J of Environ Biol 31:329-334.

Sanita di Toppi L, Gabbrielli R (1999). Response to cadmium in higher plants. Environ Exp Bot 41:105-130.

Scavroni J, Sivia Fernandes Boaro C, Ortiz Mayo Marques M, Cesar Ferreira L (2005). Yield and composition of the essential oil of Mentha piperita L. (Lamiaceae) grown with biosolid. Braz J Plant Physiol 17(4):345-352.

Scora RW, Chang AC (1997). Essential oil quality and heavy metal concentrations of peppermint grown on a municipal sludge-amended soil. J of Environ Qual 26(4):975-979.

Sengar RS, Gautam M, Garg SK, Chaudhary R, Sengar K
(2008). Effect of lead on seed germination, seedling growth, chlorophyll content and nitrate reductase activity in mung bean (Vigna radiate L.). Res J of Phytochem 2:61-68.

Shah FR, Ahmad N, Masood KR, Zahid DM (2008). The influence of cadmium and chromium on the biomass production of shisham (Dalbergia sissoo ROXB.) seedlings. Pak J of Bot 40(4):1341-1348.

Shanker AK, Cervantes C, Loza-Tavera H, Avudainayagam S (2005). Chromium toxicity in plants. Environ Int 31:6368.

Siddhu G, Ali khan MA (2012). Effects of cadmium on growth and metabolism of Phaseolus mungo. J of Environ Biol 33:173-179.

Singh S, Singh A, Bahadur R (2011). Effect of cadmium on germination and seedling growth of tomato (Lycopersicum esculentum Mill). Plant Arch 11(2):859-862.

Singh KP, Mohan D, Sinha S, Dalwani R (2004). Impact assessment of treated/untreated wastewater toxicants discharged by sewage treatment plants on health, agricultural, and environmental quality in the wastewater disposal area. Chemos 55:227-255.

Soghian S, Sinert R (2009). Toxicity, heavy metals. http:// emedicine.medscape.com/article/8149 60-Overview.

Srivastava NK, Luthra R (1994). Relationship between photosynthetic carbon metabolism and essential oil biogenesis in peppermint under Mn stress. J Exp Botany 45:1127-1132.

Sun Y, Zhou Q, Diao Ch (2008). Effects of cadmium and arsenic on growth and metal accumulation of Cd-hyperaccumulator Solanum nigrum L. Bioresource Techn 99:1103-1110.

Street RA, Kulkarni MG, Stirk WA, Southway C, Staden J (2007). Toxicity of metal elements on germination and seedling growth of widely used medicinal plants belonging to Hyacinthaceae. Bull Environ Cont Toxic 79:371-376.

Tirillini B, Ricci A, Pintore G, Chessa M, Sighinolfi S (2006). Induction of hypericins in hypericum perforatum in response to chromium. Fitoterapia 77:164-70.

Topalov V, Zhelyazkov V (1991). Effect of harvesting on the yield of fresh material, essential oil, and planting material from Mentha piperita L. and Mentha arvensis L. Herba. Hung 50:60-67.

Van Assche F, Clijsters H (1990). Effects of heavy metals on enzyme activity in plants. Plant Cell Environ 13:195-206.

Van Balen E, Geijn VD, Desmet G (1980). Autoradiographic evidence for the incorporation of cadmium into calcium oxalate crystals. Z Pflanzenphysiol 97:123-133.

Vassilev A, Yordanov I, Tesonev T (1997). Effects of $\mathrm{Cd}^{2+}$ on the physiological state and photosynthetic activity of young barley plants. Photosynthetica 34(2):293-302.

Vassilev A, Yordanov I (1997). Reductive analysis of factors limiting growth of cadmium-treated plants: A Rev: Bulg J Plant Physiol 23(3-4):114-133.

Vazquez M, Poschenrieder Ch, Barcelo J (1989). Pulvinus structure and leaf abscission in cadmium-treated bean plants 
(Phaseolus vulgaris L.). Can J Bot 67:2756-2764.

Wei SH, Zhou QX (2004). Discussion on basic principles and strengthening measures for phytoremediation of soils contaminated by heavy metals. Chin J of Ecol 23:65-72 (in Chinese).

Wierzbicka M (1995). How lead loses its toxicity to plant. Act Soc Bot Pol 64:81-90.

Wojcik M, Vangronsveld J, Tukiendorf A (2005) Cadmium tolerance in Thlaspi caerulescens: Growth parameters, metal accumulation and phytochelatin synthesis in response to cadmium. Environ and Exp Bot 53:151-161.

Yancey P, Clark M, Hand S, Bowlus R, Somero G (1982). Living with water stress: evolution of osmolyte systems. Sci 217:1212-1222.

Yang XE, Long XX, Ye HB, He ZL, Calvert DV, Stoffella PJ (2004). Cadmium tolerance and hyperaccumulation in a new zn hyperaccumulating plant species (Sedum alfrdii Hance). Plant and Soil 259:181-189.
Zhao S, Ye X, Zheng J (2011). Lead-induced changes in plan morphology, cell ultrastructure, growth and yields of tomato. Afric J of Biot 10(50):10116-10124.

Zheljazkov VD, Craker LE, Xing B (2006). Effects of Cd, Pb, and $\mathrm{Cu}$ on growth and essential oil contents in dill, peppermint, and basil Environ and Exp Bot 58:9-16.

Zheljazkov VD, Nielsen NE (1993). Studies on the effect of heavy metals $(\mathrm{Cd}, \mathrm{Pb}, \mathrm{Cu}, \mathrm{Mn}, \mathrm{Zn}$ and $\mathrm{Fe}$ ) upon the growth, productivity and quality of lavander (Lavandula vera D. C.) Production. A paper presented at the $24^{\text {th }}$ international symposium on essential oils. Berlin. J Essential Oil Res.

Zheljazkov VD, Nielson NE (1996). Effect of heavy metals on peppermint and cornmint. Plant Soil 178:59-66.

Zheljazkov VD, Philip R (2003). Source-separated municipal solid waste compost application to swiss chard and basil. Heavy metals in the environment. technical report. 